\title{
A physiological perspective on the ecology and evolution of partial migration
}

\author{
Arne Hegemann ${ }^{1} \cdot$ Adam M. Fudickar $^{2,3}$ • Jan-Åke Nilsson ${ }^{1}$ (1)
}

Received: 17 December 2018 / Revised: 25 February 2019 / Accepted: 28 February 2019 / Published online: 19 March 2019

(c) The Author(s) 2019

\begin{abstract}
Billions of animals migrate between breeding and non-breeding areas worldwide. Partial migration, where both migrants and residents coexist within a population, occurs in most animal taxa, including fish, insects, birds and mammals. Partial migration has been hypothesised to be the most common form of migration and to be an evolutionary precursor to full migration. Despite extensive theoretical models about partial migration and its potential to provide insight into the ecology and evolution of migration, the physiological mechanisms that shape partial migration remain poorly understood. Here, we review current knowledge on how physiological processes mediate the causes and consequences of avian partial migration, and how they may help us understand why some individuals migrate and others remain resident. When information from birds is missing, we highlight examples from other taxa. In particular, we focus on temperature regulation, metabolic rate, immune function, oxidative stress, telomeres, and neuroendocrine and endocrine systems. We argue that these traits provide physiological pathways that regulate the ecological and behavioural causes and/or consequences of partial migration, and may provide insight into the mechanistic basis of wintering decisions. They may, thus, also help us to explain why individuals switch strategies among winters. We also highlight current gaps in our knowledge and suggest promising future research opportunities. A deeper understanding of the physiological mechanisms mediating the causes and consequences of partial migration will not only provide novel insights into the ecology and evolution of migration in general, but will also be vital to precisely modelling population trends and predicting range shifts under global change.
\end{abstract}

Keywords Ecophysiology $\cdot$ Ecoimmunology $\cdot$ Hormones $\cdot$ Metabolism $\cdot$ Movement ecology $\cdot$ Avian life history

\section{Zusammenfassung}

Weltweit ziehen Milliarden von Vögeln zwischen Brut- und Überwinterungsgebieten. Eine der häufigsten Zugformen ist Teilzug. Bei Teilzug gibt es innerhalb einer Population sowohl Zugvögel als auch Standvögel. Diese Form des Zuges gibt es in fast allen Tiergruppen, von Fischen über Insekten und Vögel bis hin zu Säugetieren. Teilzug ist möglicherwiese die evolutionäre Frühform von vollständigem Zug. Obwohl es viele theoretische Modelle über Teilzug gibt und Teilzug das Potential hat uns viele Einblicke in die Ökologie und Evolution von Zugverhalten zu geben, sind die physiologischen Mechanismen die Teilzug regulieren weitgehend unbekannt. In dieser Literaturübersicht fassen wir das derzeitige Wissen wie physiologische Prozesse die Ursachen und Folgen von Teilzug regulieren zusammen. Wir zeigen auf wie ein Verständnis der physiologischen Prozesse uns dabei helfen kann zu verstehen warum manche Individuen ziehen und andere Standvögel sind. Unsere Literaturübersicht fokussiert sich auf Wissen an Vögeln, aber wenn solches Wissen nicht vorhanden ist, greifen wir auf Beispiele von anderen Tiergruppen zurück. Wir fokussieren uns auf die folgenden physiologischen Systeme: Regulierung der Körpertemperatur, Stoffwechselrate, Immunsystem, oxidativer Stress, Telomere, neuroendokrine und hormonelle Kreisläufe. Wir argumentieren, dass diese physiologischen Systeme die ökologischen und verhaltensbiologischen Ursachen und/oder

Communicated by N. Chernetsov.

This article is a contribution to the Topical Collection 27th

International Ornithological Congress, Vancouver, Canada, 19 to

26 August 2018.

Extended author information available on the last page of the article 
Folgen von Teilzug regulieren und damit mechanistische Erklärungen für unterschiedliche Winterstrategien liefern können. Sie können daher womöglich auch erklären warum manche Individuen die Überwinterungsstrategie wechseln und in einem Winter ziehen und in einem anderen Winter nicht ziehen. Weiterhin identifizieren wir Wissenslücken und machen Vorschläge für vielversprechende zukünftige Forschungsprojekte. Ein besseres Verständnis der physiologischen Mechanismen von Ursachen und Konsequenzen von Teilzug wird nicht nur vorteilhaft sein für die allgemeine Erforschung von Ökologie und Evolution von Zugverhalten, sondern ist auch notwendig um Populationsentwicklungen und Arealverschiebungen in Folge des globalen Wandels vorherzusagen.

\section{Introduction}

Across the globe billions of animals from all major taxonomic groups migrate between breeding and non-breeding areas. While migration of entire populations is the most obvious type of migration, a more common form is partial migration. Partial migration is defined as populations containing both migratory and resident individuals (Lack 1943; Gauthreaux 1982; Terrill and Able 1988), and has been hypothesised to be an evolutionary precursor to full migration (Berthold 1996). Partial migration exists in a wide array of taxa including fish, insects and mammals (Chapman et al. 2011; Reid et al. 2018) and is particularly widespread among birds (Table 1). Partial migration provides the opportunity to test general hypotheses of the causes, consequences and adaptations to residency and migration, by comparing migrants and residents within the same population (Adriaensen and Dhondt 1990; Chapman et al. 2011; Reid et al. 2018). Further, studying partial migration has the potential to provide insight into the evolutionary origins and mechanisms supporting the coexistence of different life history strategies in sympatric taxa (Lundberg 1988; Chapman et al. 2011).

\section{Why are some individuals migrants whereas others remain residents?}

The causes and consequences of migration and residency within partially migratory populations have been hypothesised to be linked to both intrinsic (e.g. genetic variation) and extrinsic (e.g. access to resources) factors (Schwabl and Silverin 1990; Newton 2008; Pulido and Berthold 2010; Pulido 2011). From an evolutionary perspective, different life history strategies reflect different adaptations to optimize fitness (Stearns 1976). If residents have increased residual reproductive success compared to migrants, then residency should be at a selective advantage, leading to fixed residency at the population level. However, if migration results in higher fitness, then migration will be at a selective advantage and eventually become the main and only strategy. If fitness differences between migrants and residents are small or vary across years, then migrants and residents could coexist within the same population, resulting in partial migration (Lundberg 1987, 1988; Kaitala et al. 1993; Griswold et al. 2011; Pulido 2011; Lundberg 2013). If being migratory or resident is not purely strategic, extrinsic factors have been suggested to explain why some individuals migrate and others remain resident. In this case, migration and residency will not yield the same fitness outcome. Depending on the conditions, the state of the individual or the environmental harshness, some individuals have to make do with the best of a bad job (Lundberg 1988; Kokko 2011). Such conditional strategies are often based on behavioural differences in the propensity to migrate such as individual differences in response to adverse weather, competition for food, pressure from predators, and intrinsic differences associated with age and sex (Ketterson 1979; Schwabl 1983; Able and Belthoff 1998; Coppack and Pulido 2009; Jahn et al. 2010; Fudickar et al. 2013). However, the underlying physiological mechanisms, which are crucial to an explanation for why some individuals migrate and others remain resident, have received much less attention. In this review, we aim to summarize and highlight the existing knowledge on some of the key physiological mechanisms that contribute to differences in migratory behaviour in partially migratory populations. We also aim to identify current knowledge gaps and suggest future lines of research that we think will help elucidate the causes and consequences of partial migration.

In our review, we will distinguish between two different partial migration patterns (Fig. 1): all individuals in the population breed in the same area but part of the population migrates from the breeding grounds during the non-breeding season (scenario A, Fig. 1); alternatively, the whole population spends the non-breeding season in the same place but some individuals migrate in some years to breed elsewhere, while they remain on the wintering grounds for breeding in other years (scenario B, Fig. 1). Following Chapman et al. (2011), we call these two types of partial migration 'nonbreeding' and 'breeding partial migration', respectively, based on the season in which the population is allopatric (Fig. 1). Non-breeding partial migration is the most common of the two systems, and unless we explicitly state otherwise, we refer to this system here. Only when studies on the physiological mechanisms do not exist for such partial 
Table 1 Examples of studies on partial migration illustrating its widespread occurrence among bird families worldwide

\begin{tabular}{|c|c|c|c|c|}
\hline Species & Order & Family & Continent & References \\
\hline $\begin{array}{l}\text { European Shag (Phalacrocorax } \\
\text { aristotelis) }\end{array}$ & Suliformes & Phalacrocoracidae & Europe & Grist et al. $(2014,2017)$ \\
\hline Cattle Egret (Ardeola ibis) & Pelecaniformes & Ardeidae & Australia & McKilligan et al. (1993) \\
\hline $\begin{array}{l}\text { Cory's Shearwater (Calonectris } \\
\text { borealis) }\end{array}$ & Procellariiformes & Procellariidae & $\begin{array}{l}\text { Northwest and Central } \\
\text { South Atlantic }\end{array}$ & Perez et al. (2014) \\
\hline Osprey (Pandion haliaetus) & Accipitriformes & Pandionidae & North America & Martell et al. (2004) \\
\hline Cape Griffon (Gyps coprotheres) & Accipitriformes & Accipitridae & Africa & Boshoff et al. (2009) \\
\hline Eurasian Kestrel (Falco tinnunculus) & Falconiformes & Falconidae & Europe & Aparicio (2000) \\
\hline $\begin{array}{l}\text { Greater Sage-Grouse (Centrocercus } \\
\text { urophasianus) }\end{array}$ & Galliformes & Phasianidae & North America & Pratt et al. (2017) \\
\hline Satyr Tragopan (Tragopan satyra) & Galliformes & Phasianidae & Asia & Norbu et al. (2017) \\
\hline Great Bustard (Otis tarda) & Otidiformes & Otididae & Europe & Palacin et al. $(2011,2012)$ \\
\hline Pied Avocet (Recurvirostra avosetta) & Charadriiformes & Recurvirostridae & Europe & Chambon et al. (2018) \\
\hline $\begin{array}{l}\text { Kittlitz's Plover (Charadrius pec- } \\
\text { uarius) }\end{array}$ & Charadriiformes & Charadriidae & Africa & Lipshutz et al. (2011) \\
\hline $\begin{array}{l}\text { Yellow-legged Gull (Larus } \\
\text { michahellis) }\end{array}$ & Charadriiformes & Laridae & Europe & Kralj et al. (2018) \\
\hline Atlantic Puffin (Fratercula arctica) & Charadriiformes & Alcidae & Europe/Atlantic Ocean & Harris et al. (2013) \\
\hline $\begin{array}{l}\text { Wandering Albatross (Diomedea } \\
\text { exulans) }\end{array}$ & Procellariiformes & Diomedeidae & Antarctica & Weimerskirch et al. (2015) \\
\hline $\begin{array}{l}\text { Lanyu Scops Owl (Otus elegans } \\
\text { botelensis) }\end{array}$ & Strigiformes & Strigidae & Asia & Bai et al. (2012) \\
\hline $\begin{array}{l}\text { Red-headed Woodpecker (Melanerpes } \\
\text { erythrocephalus) }\end{array}$ & Piciformes & Picidae & North America & Vukovich and Kilgo (2013) \\
\hline Eurasian Hoopoe (Uрира ерорs) & Bucerotiformes & Upupidae & Europe & van Wijk et al. (2018) \\
\hline American Dipper (Cinclus mexicanus) & Passeriformes & Cinclidae & North America & $\begin{array}{l}\text { Middleton et al. (2006); Gillis et al. } \\
\text { (2008) }\end{array}$ \\
\hline Eurasian Skylark (Alauda arvensis) & Passeriformes & Alaudidae & Europe & Hegemann et al. $(2010,2015)$ \\
\hline European Blackbird (Turdus merula) & Passeriformes & Turdidae & Europe & Fudickar et al. (2013) \\
\hline $\begin{array}{l}\text { Ash-throated Casiornis (Casiornis } \\
\text { fuscus) }\end{array}$ & Passeriformes & Tyrannidae & South America & Lees (2016) \\
\hline Masked Weaver (Ploceus velatus) & Passeriformes & Ploceidae & Africa & Herremans (1994) \\
\hline $\begin{array}{l}\text { White-ruffed Manakin (Corapipo } \\
\text { altera) }\end{array}$ & Passeriformes & Pipridae & Central America & Boyle $(2008,2011)$ \\
\hline European Robin (Erithacus rubecula) & Passeriformes & Muscicapidae & Europe & Adriaensen and Dhondt (1990) \\
\hline Blue Tit (Cyanistes caeruleus) & Passeriformes & Paridae & Europe & $\begin{array}{l}\text { Smith and Nilsson (1987), Nilsson et al. } \\
\text { (2006) }\end{array}$ \\
\hline Silvereye (Zosterops lateralis) & Passeriformes & Zosteropidae & Australia & Chan (1995) \\
\hline
\end{tabular}

We emphasize that this list is designed to show the diversity among orders and regions rather than give an exhaustive record of partial migrants. For additional species see, for example, the reviews by Chan (2001), Jahn et al. (2012) and Boyle (2017)

migratory systems do we consider two related migratory systems. First, systems in which migratory and resident subspecies or populations overwinter together but breed separately. Second, systems of inter-population partial migration, e.g. where sedentary and migratory populations occur in different geographic parts of the distribution range (cf. Dingle 2008). We do not consider these two systems to be examples of true partial migration because, for partial migration to occur, regular gene flow between migrants and residents should exist (beyond dispersal). Therefore, in the case of breeding partial migration, this system also only qualifies as partial migration when migratory individuals readily change strategies between years to become residents. Non-breeding and breeding partial migration can further be divided into obligate partial migration and facultative partial migration (Terrill and Able 1988). Obligate partial migration refers to individuals that always follow the same strategy (migration or residency) based on their genetic makeup or other endogenous control systems. Those individuals stick to one strategy throughout their life, regardless of their physiological state, environmental conditions or population densities. Facultative (conditional) partial migrants refers to those 

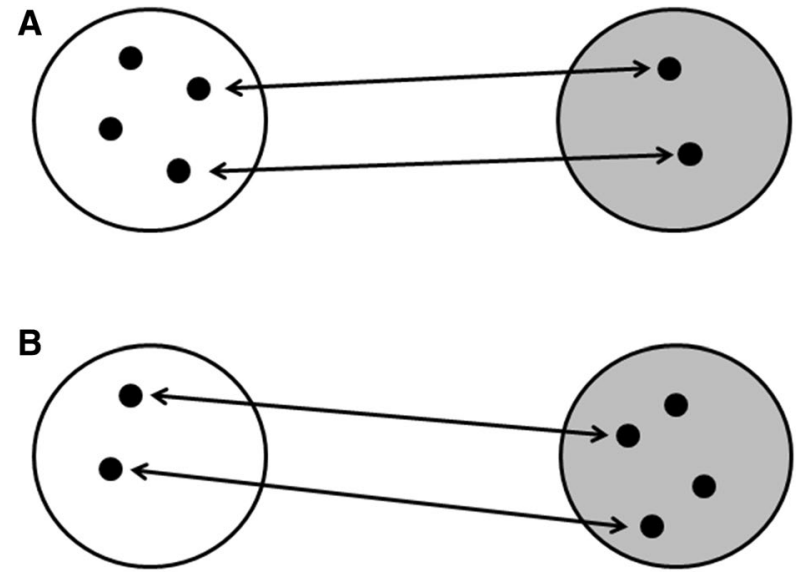

Breeding season

Non-breeding season

Fig. 1a, b Schematic representation of partial migration. a The population is sympatric during the breeding season (non-breeding partial migration), and $\mathbf{b}$ the population is sympatric during the non-breeding season (breeding partial migration)

individuals that select a strategy depending on environmental conditions, their own physiological state or population densities, and is a decision that might differ between years. However, distinction between obligate and facultative partial migration is sometimes difficult and there may be thresholds for these at different developmental stages (Chapman et al. 2011). Such thresholds of migration might be determined by environmental conditions (Pulido 2011).

\section{Physiological systems}

In the following section, we highlight physiological systems that have been linked to either a cause or consequence of partial migration. We focus on studies that have been done on partial migration systems in birds according to our definition above. Where information is lacking for partially migratory birds, we highlight what is known from other migratory systems or from other animal taxa. To facilitate knowledge transfer to evolutionary biologists and ecologists not familiar with physiology, we begin each section with a short introduction to the physiological system. To suggest avenues for future research, we end each paragraph with an outline of open questions.

\section{Thermoregulation}

Thermoregulation is a major challenge during cold winter conditions, especially for small animals. In most nonbreeding partial migration systems, migratory individuals escape cold and harsh environments by migrating to warmer latitudes. We should, therefore, expect resident individuals that endure harsh winter conditions at the breeding grounds to adapt or adjust to facilitate thermoregulation. One such adaptation is increased body size (i.e. resulting in a higher volume:surface ratio), which provides an advantage due to better physiological tolerance of harsh conditions (Ketterson and Nolan 1976). This results in a latitudinal increase in body size, known as Bergmann's rule, which has recently been verified for mammals (Clauss et al. 2013). By having a more advantageous surface-volume ratio, large individuals are more cold tolerant as heat is more easily conserved within the body than in smaller individuals. Furthermore, large size also confers an advantage due to increased fasting endurance because the amount of resources that can be stored by the body is directly proportional to body mass, whereas metabolic rate has a less steep relation to body mass. Thus, larger individuals can store larger fuel reserves in relation to metabolic rate than smaller individuals (Calder 1974). Examples of the thermal tolerance or fasting endurance hypotheses are given by sex-differential migration propensities in species with sexual size dimorphism. In House Finches (Carpodacus mexicanus) the larger sex, i.e. males, are more common among residents at the breeding grounds than females, although females are the dominant sex (Belthoff and Gauthreaux 1991). Colder and snowier areas were occupied by larger individuals during winter than less harsh environments in Snow Buntings (Plectrophenax nivalis) (Macdonald et al. 2016), and larger individuals were more likely to be resident in Skylarks (Alauda arvensis) (Hegemann et al. 2015). Female White-Ruffed Manakins (Corapipo altera) are larger than the males, and they tend to be more likely to stay resident compared to males when foraging opportunities deteriorate (Boyle 2008).

Even though the thermal tolerance hypothesis has usually been evaluated in the light of heat conservation, it can just as well be applied to systems where heat dissipation is a problem. In hot environments, large size will be at a disadvantage since a smaller surface area in relation to volume will impede heat dissipation. In such environments, activities such as foraging induce internal, work-related heat production resulting in increased body temperature (Nilsson et al. 2016; Nilsson and Nord 2018). To reduce the likelihood of overheating, large individuals in particular need to engage in costly thermoregulation with consequences for energy and water balance (Smit et al. 2018). Amongst bird species, sexual size dimorphism is greatest in the Great Bustard (Otis tarda): males are about 2.5 times bigger than females (Alonso et al. 2009a). During hot summers at breeding grounds in central Spain, Great Bustards, especially males, are at risk of overheating. Therefore, immediately following the mating season, a high proportion of males migrate to areas with lower mean ambient temperatures (Alonso et al. 2009b). In line with this, males from breeding areas 
with high ambient temperatures have a higher tendency to migrate. Thus, this partial migration system seems to be driven by thermal tolerance, but instead of this giving larger individuals an advantage [which was originally suggested by Ketterson and Nolan (1976)], they actually need to migrate in order to reduce the costs of thermoregulation.

In general, birds adjust their physiological systems as winter is approaching to increase their cold tolerance (Swanson 2010). Such winter acclimatization includes increases in shivering endurance as shivering thermogenesis, primarily in the large flight muscles, is the main way to generate heat in birds. This typically occurs together with an increased summit metabolic rate, resulting in an increase in sustained heat production compared to in the summer (Swanson 2010). In parallel to physiological adjustments, birds in general adjust their insulation in preparation for the winter by replacing their feathers. The insulating quality of feathers, which results in decreased thermal conductance, increases dramatically after the autumnal moult (Novoa et al. 1994; Cooper 2002). However, cold tolerance also increases with latitude, both as metabolic adjustments (Khaliq et al. 2017) and as decreased thermal conductance (Swanson 1993). Thus, it is tempting to suggest that residents in partially migrating populations develop increased cold tolerance as a consequence of being sedentary. Alternatively, reduced cold tolerance in some individuals in the same population could explain why they become migrants. Thus, it would be interesting to quantify if resident individuals, particularly among small birds of northern latitudes or high altitudes, differ from migratory individuals in feather quality. If they do, does this have any effect on their reproductive investment during summer, when heat dissimilation could limit metabolism (Nilsson and Nord 2018)? Or is it possible for them to increase thermal conductance by, for example, losing feathers (as opposed to feather loss in the regular moult and in the formation of the brood patch)?

Few studies have made direct comparisons of cold tolerance, shivering capacity or plumage characteristics between migrants and residents from the same population. Cold tolerance can be estimated by measuring the energetic cost of thermoregulation. This was done for resident and migratory juvenile Blue Tits (Cyanistes caeruleus) from southern Sweden at a nocturnal ambient temperature of $0{ }^{\circ} \mathrm{C}$. Resident males had a significantly lower cost of thermoregulation than resident females or either sex of the migrants (Nilsson et al. 2011). Since around $75 \%$ of migrating Blue Tits caught at the ringing station of Falsterbo, southern Sweden, were juvenile females (Smith and Nilsson 1987; Heldbjerg and Karlsson 1997), and males are dominant to females in this species, the migratory strategy is thought to be conditional on dominance (Smith and Nilsson 1987). Hence, sub-dominant individuals need to migrate. Additionally, migrating juvenile males hatched later than resident males, indicating that migrants were also sub-dominant within the sex group (Smith and Nilsson 1987). However, it might also be that late-hatched males had a shorter time to complete their moult. Sub-dominancy and/or time constraints may then result in a compromised moult leading to the production of plumage with low insulating properties (cf. Nilsson and Svensson 1996) in migrating juvenile Blue Tits (Nilsson et al. 2011). In such cases, migration might be induced in these individuals to enable them to avoid the high thermoregulatory costs that they would face should they remain as residents.

We encourage more studies to investigate variation in cold tolerance among partial migrants. Particularly rewarding might be studies investigating to what degree metabolic adjustments and/or plumage quality could be a consequence of being resident or migratory (in systems based on obligate strategies) or could be a cause (in systems based on conditional strategies) of becoming resident or migratory.

\section{Metabolic rate}

Both thermoregulation through long winter nights and migration are energetically costly activities. Consequently it is hard to predict which of the two strategies, viz. residency or migration, is the energetically most demanding. Increased basal metabolic rate (BMR) has been inferred as physiological preparation to sustain high work rates (Nilsson 2002; Swanson 2010), probably as a result of increased feeding and assimilation. Thus, BMR increases with the need for thermoregulation (Broggi et al. 2007) and in preparation for migration [at least for spring migration (Lindström 1997; Swanson 2010)]. Hence, the periods of peak metabolic rate will differ seasonally between the two strategies. In residents, metabolic rate should be highest during mid-winter (Broggi et al. 2007). In migratory individuals, it should be highest during migration (Kersten et al. 1998). However, very few estimates of BMR have been conducted on partial migrants during the relevant seasons. To the best of our knowledge, the only study that estimated BMR in both residents and migrants at the same time found that migrating Blue Tits, measured en route, had lower BMR than residents (Nilsson et al. 2011). Thus, according to these data, residents prepare themselves for a future higher sustained work rate than migrants. Alternatively, low BMR phenotypes might have to migrate to escape the high work rate induced by thermoregulation during winter. The reduction in BMR among migrants is contrary to results indicating an increase in BMR in preparation for migration, especially during periods of 'refuelling' (Lindström et al. 1999). However, Blue Tits migrate extremely slowly and may mostly use a fly-andforage strategy when migrating (Nilsson et al. 2008), which can be assumed to be far less energetically costly than traditional flight bouts of migrants. In Three-Spined Sticklebacks 
(Gasterosteus aculeatus), a high metabolic rate and swimming activity have been related to high levels of thyroid hormones (Kitano et al. 2010), and migrating individuals had higher levels of these hormones than residents (Kitano et al. 2012). Potentially, the level of these hormones might also serve as proxies for metabolic rate in birds. Studies comparing metabolic rates or thyroid hormone levels between residents and migrants in different stages of the annual cycle will shed light on the role of metabolic differences in partial migration.

\section{Immune system}

The immune system is of fundamental importance for self-maintenance and promotes survival by reducing the probability of disease-related mortality (Roitt et al. 1998), but it simultaneously incurs costs in terms of its production, maintenance and activation (Klasing 2004). These cost-benefit trade-offs make immune function a powerful driver of individual differences in many evolutionary and ecological processes (Hasselquist and Nilsson 2012). For example, differences in innate immune function translate into different survival probabilities (Wilcoxen et al. 2010; Hegemann et al. 2013b, 2015). Furthermore, trade-offs between reproductive effort and investment into immune function are well documented (e.g. Ilmonen et al. 2000; Ardia et al. 2003, Hasselquist and Nilsson 2012; Hegemann et al. 2013b). Finally, investment into immune function is adjusted in relation to parasite pressure (Horrocks et al. 2012, 2015; Hegemann et al. 2012a). With respect to migration, it has been hypothesised that migrants need to reduce immune function during the physiologically demanding migration seasons (Hasselquist 2007; Buehler and Piersma 2008). A contrasting hypothesis proposes that migrants need to boost immune function because they encounter more and/or different pathogens during their journeys (Møller and Erritzoe 1998; Buehler et al. 2010), and high densities of birds on stopover sites can cause high levels of disease transmission (van Dijk et al. 2014). Finally, the physical activity of migratory flights per se may have possible effects on immune function and hence disease susceptibility (van Dijk and Matson 2016). Partial migration offers an ideal setting to test these hypotheses as residents and migrants from the same population can be compared. The first evidence that residents and migrants within a population of partial migrants differ in innate immune function comes from Skylarks (Hegemann et al. 2015). When measured during the breeding season, birds that migrated the previous winter tended to have higher complement activity, which is part of innate immune function, than birds that were resident in the previous winter. This pattern was consistent across 4 study years supporting the hypothesis that migrants do need to boost their immune function. Survival differences between migrants and residents were also related to differences in innate immune function (Hegemann et al. 2015). In European Blackbirds (Turdus merula), innate immune function differed between residents and migrants when measured during autumn migration at the same time and location (Eikenaar and Hegemann 2016). In this latter study, migrants had lower parameters of innate immune function compared to residents, which supports the hypothesis that innate immune function is compromised during migration. However, migrants and residents originated from different breeding populations, so the observed differences could also be explained by population-specific patterns. In the Skylark, within-individual data suggested that immune function could potentially even be directly involved in the decision regarding whether an individual remains resident or migrates (Hegemann et al. 2015). Hegemann et al. (2015) hypothesised that individuals which are sick or parasitized need to invest into an acute immune response. Such a response includes a range of energetically, physiologically and behaviourally costly adjustments (Lee et al. 2005; OwenAshley et al. 2006; Owen-Ashley and Wingfield 2007; Hegemann et al. 2012b, 2013a, 2018; Sköld-Chiriac et al. 2015). Consequently, infected individuals might not be able to afford a demanding migration and hence have to become resident. Such a physiological mechanism could also explain why individuals switch strategies between winters. However, the data are correlational and were collected after the winter season, i.e. were only relevant to individuals that survived a winter. Hence, it remains to be tested if differences in immune function are the cause or the consequence of partial migration. Furthermore, differences in pathogen transmission between resident and migratory individuals, and a temporary escape from pathogen pressure in migrants and higher mortality of infected individuals during migration have all been suggested to contribute to the evolution of partial migration (Shaw and Binning 2016; Brown and Hall 2018). However, empirical studies measuring pathogen dynamics and their corresponding immune responses throughout the annual cycle in both resident and migratory individuals of partially migrating populations are lacking.

\section{Oxidative stress}

Oxidative stress results in damage to biomolecules due to an imbalance between damaging pro-oxidants and protective antioxidants in organisms. Enzymatic and non-enzymatic antioxidants normally neutralize free radicals, which are produced in cells as by-products of metabolic processes (Monaghan et al. 2009; Costantini 2014). If antioxidants are depleted and/or free radicals accumulate, oxidative stress 
occurs and this can lead to fitness costs (Bize et al. 2008). Intense physical activities like migration, thermogenesis and fatigue increase oxidative stress (Costantini et al. 2007; Jenni-Eiermann et al. 2014), probably because reactive oxygen species leak through the mitochondrial membrane as a consequence of a high metabolic rate. Thus, migrants risk suffering from oxidative stress during autumn and spring migrations, whereas residents run this risk during the winter months due to thermogenesis. In a comparison of migratory and resident European Blackbirds caught at the same place and time (although the migrants originated from a different breedingpopulation), Eikenaar et al. (2017) found evidence that migratory individuals invested more in antioxidant defences, probably by producing or ingesting more antioxidants. This suggests that migrants (need to) boost their antioxidant capacity in order to counteract increased pro-oxidant levels due to high activity levels. Apparently, this adjustment successfully prevents oxidative damage, as migrants and residents did not differ in their degree of lipid damage (Eikenaar et al. 2017). Interestingly, in the same system, migrating Blackbirds had lower parameters of innate immune function compared to residents (Eikenaar and Hegemann 2016). As immune function and immune responses can cause oxidative stress (von Schantz et al. 1999; Costantini and Moller 2009), this led to the hypothesis that migrants may need to down-regulate immune function during their energy-demanding migration when oxidative stress is highest (Eikenaar et al. 2018a). Indeed, when comparing migrating and resident Blackbirds at the same time and place, baseline innate immune function was negatively correlated with antioxidant capacity in migrating individuals, but not in the less energetically and physiologically challenged residents (Eikenaar et al. 2018a). This suggests that migrants trade-off antioxidant defences with immune function during migration, while residents do not appear to make the same trade-off (Eikenaar et al. 2018a).

A way for birds to boost their antioxidant capacity (to counteract the negative effects of pro-oxidants) is to selectively forage on antioxidant-rich fruits (Cooper-Mullin and McWilliams 2016), a behaviour often seen in migrants during autumn (Bolser et al. 2013). The intake of certain fruit components such as anthocyanins, in particular, likely reduces oxidative stress and additionally stimulates immune responses (Catoni et al. 2008; Cooper-Mullin and McWilliams 2016). When resident and migratory species were compared, migratory species indeed selected sugar- and antioxidant-rich fruits (Albrecht et al. 2018), which enhance the build-up of body fat as fuel for migration and are beneficial for oxidative status and immune function (Catoni et al. 2008; Cooper-Mullin and McWilliams 2016). In contrast, generalist frugivorous residents favoured lipid-rich fruits, which helped to maximize their energy intake (Albrecht et al. 2018). Hence, in a partially migratory population, one might expect migratory individuals to eat more sugar- and antioxidant-rich fruits just before migration starts than their resident conspecifics. Similar patterns may exist for purely insectivorous species, where migrants could increase their intake of grazing insects, which usually contain more antioxidants than predatory insects. However, to the best of our knowledge, these ideas have not yet been tested. Furthermore, we know very little about the risk of oxidative stress between individuals from the same population that are either resident or migrant, as measured during the relevant season, viz. during mid-winter for residents and during migration for migrants, or on the breeding grounds just after migration has been completed. To the best of our knowledge, this type of study only currently exists for fish. In partially migrating Brown Trout (Salmo trutta), migrating individuals had, on average, higher oxidative stress compared to residents when measured at the spawning grounds shortly after migration (Peiman et al. 2017a). Antioxidant capacity did not differ between migrants and residents, which suggests that migrants had more pro-oxidants that caused increased oxidative damage. This may have been the result of their recent migration, which would support the hypothesis that migration causes higher oxidative stress in partially migrating individuals. However, Peiman et al. (2017a) also discuss a number of alternative explanations that are not directly linked to the energetic cost of migration. Hence, it remains to be tested in which season the most oxidative stress in partial migrants occurs. In a global warming scenario, it can be predicted that the cost of oxidative stress will be alleviated in residents due to a reduced work rate for thermoregulation, whereas it will stay the same for migrants (if their migration distance stays constant).

\section{Telomeres}

Telomeres are repetitive non-coding DNA regions that protect the ends of chromosomes. With each cell division telomeres shorten and if telomeres become too short, cell death occurs (Monaghan 2010). Short telomeres and high telomere loss rate have been linked to reduced survival in free-living birds (Salomons et al. 2009; Wilbourn et al. 2018). High physical activity and the resulting oxidative stress are well-known causes of telomere shortening (Monaghan 2010). Since both migration (Wikelski et al. 2003) and thermoregulation in cold environments (Broggi et al. 2004; Swanson 2010) are energy consuming and can increase oxidative stress (see section Oxidative stress), it is not straightforward to predict which wintering strategy (migration or residency) accelerates telomere shortening the most. Furthermore, if the different strategies are related to different probabilities of parasite infection (see section Immune function), this may also influence telomere shortening because activation of the immune system can cause 
oxidative stress (Costantini and Moller 2009) and telomere length decreases faster in birds with (chronic) infections (Asghar et al. 2015). However, telomere length is also positively related to an individual's ability to mount an immune response and fight acute infections (Ilmonen et al. 2008). If a strategy involves increased telomere shortening, this might also have an effect on an organism's ability to fight pathogens and hence affect disease-related mortality (see section Immune function). Thus, changes in telomeres might have the potential to help us explain survival differences between migrants and residents. Yet, to the best of our knowledge, no study has yet been carried out comparing telomere length or telomere shortening rates between residents and migrants within a partially migrating population. However, in a comparison of two subspecies of Slate-Coloured Juncos (Junco hyemalis) that winter in the same area, first-year migrants had shorter telomeres than first-year residents (Bauer et al. 2016a). As only migration differed between these birds, this may suggest that telomeres shortened faster among migrating birds. However, the starting length of telomeres and their shortening rate during development were not know for these populations. Hence, it remains to be tested which of the two strategies is connected to the largest risk of telomere shortening, and could potentially help explain physiological mechanisms related to differences in survival between residents and migrants.

\section{Neuroendocrine and endocrine systems}

The neuroendocrine and endocrine systems play major roles in the responses of birds to predictable (seasonal) and unpredictable changes in the environment. Measured differences in circulating levels of hormones during autumn and spring indicate that the hormonal mechanisms controlling migration in partially migratory systems might differ for the two seasons, though this has yet to be resolved (Ramenofsky 2011). Here, we summarize current research on two endocrine systems that have been investigated for their functional role in migration in partially migratory birds: the hypothalamic-pituitary-gonadal axis (HPG) and the hypothalamic-pituitary-adrenal axis (HPA).

With respect to seasonal changes in hormones, in most temperate breeding species, the vernal increase in the duration of daylight (photoperiod) results in the seasonal activation of the avian HPG, the endocrine system that plays a central role in reproduction (Dawson et al. 2001). The seasonal activation of the HPG results from the release of gonadotropin-releasing hormone by the hypothalamus. This stimulates the pituitary to release follicle-stimulating hormone and luteinizing hormone, which then stimulate the release of testosterone, estradiol, and progesterone by the gonads (Scanes 2015). Following reproduction, the HPG typically 'shuts down' until the following winter/spring, when the photoperiod begins to increase again. An overlap between the activity of HPG and reproductive hormones with vernal migration has led researchers to ask if reproductive hormones could play a functional role in preparations for, and onset of, migration. While studies on partially migratory birds are limited, the experimental elevation of testosterone in obligate migrants [Dark-Eyed Junco (Junco hyemalis) and Grey Catbird (Dumetella carolinensis)] under a vernal like photoperiodic shift, resulted in increases in migratory condition (fat, mass, and food intake) and nocturnal activity, suggesting a potential role for testosterone in vernal migration (Tonra et al. 2011; Owen et al. 2014). Early work investigating the potential contribution of luteinizing hormone and androgens to autumn migration found no clear patterns in partially migratory European Blackbirds and Willow Tits (Poecile montanus) (Ekman 1979; Schwabl et al. 1984; Silverin 1984; Silverin et al. 1989; Schwabl and Silverin 1990). However, female European Blackbirds with high nocturnal activity in the autumn had higher circulating levels of $5 \alpha$-dihydrotestosterone ( $5 \alpha \mathrm{DHT}$ ) compared to individuals with low nocturnal activity (Schwabl and Silverin 1990). $5 \alpha \mathrm{DHT}$, which is formed by the conversion of testosterone, binds to androgen receptors, which suggests a potential role for the HPG in autumn migratory behaviour in female partially migratory European Blackbirds. Future work, in particular that which experimentally alters circulating levels of HPG hormones in vernal and autumnal migratory periods, is needed to disentangle their functional roles in migratory strategies in partially migratory populations.

As with the HPG, circulating levels of hormones produced by the HPA vary seasonally in response to predictable changes (McEwen and Wingfield 2003; Crespi et al. 2013). The HPA also plays a central role in organismal responses to unpredictable changes in the environment, such as adverse weather conditions and reduced access to food (McEwen and Wingfield 2003). Changes in levels of the glucocorticoid hormone corticosterone can mediate life history transitions, and support physiology and behavioural transitions that facilitate resource acquisition and energy (Crespi et al. 2013). Corticosterone levels increase following hypothalamic release of corticotropin-releasing hormone, which stimulates the pituitary to release adrenocorticotropic hormone resulting in stimulation of adrenal secretion of glucocorticoids (Carsia 2015). It is not surprising, given the role of corticosterone in energy mobilization, that several studies have found that it is elevated during migration in birds (Holberton 1999; Nilsson and Sandell 2009; Eikenaar et al. 2014). In partially migratory European Blackbirds, migratory individuals had higher fat levels and tended to have higher circulating corticosterone levels compared to resident individuals in the weeks just prior to their autumn departure from shared breeding grounds (Fudickar et al. 2013). A recent study that compared baseline corticosterone 
in migrating and sedentary Blackbirds found higher corticosterone in migrants during autumn but not during vernal migration compared to sedentary Blackbirds (Eikenaar et al. 2015). Other avian species have been found to have elevated corticosterone prior to reproduction, regardless of migratory phenotype. This could explain the lack of difference in corticosterone levels when comparing migrant and resident Blackbirds in early spring (Romero et al. 2006; Fudickar et al. 2016; Bauer et al. 2016b). Although, as described above, there appears to be a link between corticosterone and autumn migration in birds, the functional role of the former remains unclear. A recent comparison of migrating European Blackbirds to non-migrants captured at the same location in the autumn suggests that corticosterone could play a role in linking departure cues to the decision to depart (Eikenaar et al. 2018b). Future experimental studies could help provide insight into the mechanistic link between corticosterone and migration in partially migratory bird populations. For example, a recent study on partially migratory Brown Trout found that experimentally elevated cortisol, a major glucocorticoid involved in the stress response in fish, results in advanced seasonal timing of migration in this species (Peiman et al. 2017b). While correlative studies have led to insight into potential roles for the HPA and HPG in migratory strategies of partially migratory birds, experimentation is still needed to determine causality.

\section{Conclusions and future directions}

As outlined in this review, the physiological mechanisms related to the causes and consequences of partial migration remain relatively unstudied and many open questions remain. Despite well-established theoretical models for partial migration (Lundberg 1988; Pulido 2011; Cobben and van Noordwijk 2016, 2017), we still do not know which physiological mechanisms control individual wintering decisions (i.e. migration vs. residency), and hence their long-term consequences for survival and reproduction. Furthermore, even though we know that individuals can switch strategies between years (Schwabl 1983; Able and Belthoff 1998; Fudickar et al. 2013; Hegemann et al. 2015), we still do not understand which mechanisms induce the switch (unless these are linked to the age of birds). So far, mechanisms have often been attributed to 'poor individual quality' without specifying or investigating the underlying physiology of these. Here, we provide several candidate physiological mechanisms that may solve this long-term mystery in partial migration research, but further studies are needed. Furthermore, in partially migratory systems with genetically determined strategies, it is conceivable that the two genotypes will divert in their physiological adaptations to match their different challenges. In the light of ongoing climate change, this may lead to changes in the proportions of migrants and residents. We acknowledge that (the importance of) the suggested physiological pathways might differ between species and environments. Moreover, interactions and dependencies between the different physiological systems might exist (see above). Yet, we do not see this as a disincentive, but rather as a stimulating and exciting challenge for future research.

With recent advances in tracking technology (e.g. Global Positioning System loggers, satellite transmitters, genetic tools) it becomes increasingly possible to follow individuals at high spatiotemporal resolution year-round. Combined with the recent advances in our ability to measure physiological traits in free-living animals, we are now about to enter a period where we are able to make scientific breakthroughs in understanding the physiological mechanisms of partial migration. Understanding the physiological mechanisms underlying partial migration is not only a critical step towards gaining full understanding of the ecological and evolutionary costs and benefits of different wintering strategies, but also regards the evolution of migration. Such improved knowledge is also crucially important for accurately modelling population trends (Gilroy et al. 2016), for predicting how migratory animals likely respond to a rapidly changing environment due to global change (Klaassen et al. 2012) and for developing appropriate conservation strategies (Nathan et al. 2008). We anticipate a vibrant future for partial migration research and hope this review will stimulate future research and collaborations to disentangle some of the remaining (physiological) mysteries of partial migration.

Acknowledgements Grants by the Swedish Research Council supported J. A. N. (621-2013-4386) and A. H. (2018-04278). J. A. N. and A. H. are associated with the Centre for Animal Movement Research (CAnMove) and financed by a Linnaeus grant (349-2007-8690) from the Swedish Research Council and Lund University. A. F. was supported by the Environmental Resilience Institute, funded by Indiana University's Prepared for Environmental Change Grand Challenge initiative. Two anonymous reviewers gave constructive feedback on the manuscript.

Open Access This article is distributed under the terms of the Creative Commons Attribution 4.0 International License (http://creativeco mmons.org/licenses/by/4.0/), which permits unrestricted use, distribution, and reproduction in any medium, provided you give appropriate credit to the original author(s) and the source, provide a link to the Creative Commons license, and indicate if changes were made.

\section{References}

Able KP, Belthoff JR (1998) Rapid ‘evolution' of migratory behaviour in the introduced House Finch of eastern North America. Proc R Soc B 265:2063-2071

Adriaensen F, Dhondt AA (1990) Population dynamics and partial migration of the European Robin (Erithacus rubecula) in different habitats. J Anim Ecol 59:1077-1090

Albrecht J, Hagge J, Schabo DG, Schaefer HM, Farwig N (2018) Reward regulation in plant-frugivore networks requires only weak cues. Nat Commun 9:4838 
Alonso JC, Magana M, Alonso JA, Palacin C, Martin CA, Martin B (2009a) The most extreme sexual size dimorphism among birds: allometry, selection, and early juvenile development in the Great Bustard (Otis tarda). Auk 126:657-665

Alonso JC, Palacin C, Alonso JA, Martin CA (2009b) Post-breeding migration in male Great Bustards: low tolerance of the heaviest Palaearctic bird to summer heat. Behav Ecol Sociobiol 63:1705-1715

Aparicio J (2000) Differences in the diets of resident and non-resident Kestrels in Spain. Ornis Fenn 77:169-175

Ardia DR, Schat KA, Winkler DW (2003) Reproductive effort reduces long-term immune function in breeding Tree Swallows (Tachycineta bicolor). Proc R Soc B 270:1679-1683

Asghar M, Hasselquist D, Hansson B, Zehtindjiev P, Westerdahl H, Bensch S (2015) Hidden costs of infection: chronic malaria accelerates telomere degradation and senescence in wild birds. Science 347:436-438

Bai M, Severinghaus LL, Philippart MT (2012) Mechanisms underlying small-scale partial migration of a subtropical owl. Behav Ecol 23:153-159

Bauer CM, Heidinger BJ, Ketterson ED, Greives TJ (2016a) A migratory lifestyle is associated with shorter telomeres in a songbird (Junco hyemalis). Auk 133:649-653

Bauer CM, Needham KB, Le CN, Stewart EC, Graham JL, Ketterson ED, Greives TJ (2016b) Hypothalamic-pituitary-adrenal axis activity is not elevated in a songbird (Junco hyemalis) preparing for migration. Gen Comp Endocrinol 232:60-66

Belthoff J, Gauthreaux S (1991) Partial migration and differential winter distribution of House Finches in the eastern United States. Condor 93:374-382

Berthold P (1996) Control of bird migration. Chapmann \& Hall, London

Bize P, Devevey G, Monaghan P, Doligez B, Christe P (2008) Fecundity and survival in relation to resistance to oxidative stress in a free-living bird. Ecology 89:2584-2593

Bolser JA, Alan RR, Smith AD, Li L, Seeram NP, McWilliams SR (2013) Birds select fruits with more anthocyanins and phenolic compounds during autumn migration. Wilson J Ornithol 125:97-108

Boshoff A, Barkhuysen A, Brown G, Michael M (2009) Evidence of partial migratory behaviour by the Cape Griffon (Gyps coprotheres). Ostrich 80:129-133

Boyle WA (2008) Partial migration in birds: tests of three hypotheses in a tropical lekking frugivore. J Anim Ecol 77:1122-1128

Boyle WA (2011) Short-distance partial migration of Neotropical birds: a community-level test of the foraging limitation hypothesis. Oikos 120:1803-1816

Boyle WA (2017) Altitudinal bird migration in North America. Auk 134:443-465

Broggi J, Orell M, Hohtola E, Nilson JA (2004) Metabolic response to temperature variation in the Great Tit: an interpopulation comparison. J Anim Ecol 73:967-972

Broggi J, Hohtola E, Koivula K, Orell M, Thomson RL, Nilsson JÅ (2007) Sources of variation in winter basal metabolic rate in the Great Tit. Funct Ecol 21:528-533

Brown LM, Hall RJ (2018) Consequences of resource supplementation for disease risk in a partially migratory population. Philos Trans R Soc B 373:20170095

Buehler DM, Piersma T (2008) Travelling on a budget: predictions and ecological evidence for bottlenecks in the annual cycle of long-distance migrants. Philos Trans R Soc Lond B 363:247-266

Buehler DM, Tieleman BI, Piersma T (2010) How do migratory species stay healthy over the annual cycle? A conceptual model for immune function and for resistance to disease. Integr Comp Biol 50:346-357
Calder WA (1974) Consequences of body size for avian energetics. In: Paynter RA (ed) Avian energetics. Publ 15. Nuttall Ornithological Club, Cambridge, MA, pp 86-144

Carsia RV (2015) Adrenals. In: Scanes CG (ed) Sturkie's avian physiology, 6th edn. Academic Press, Cambridge, pp 577-611

Catoni C, Schaefer HM, Peters A (2008) Fruit for health: the effect of flavonoids on humoral immune response and food selection in a frugivorous bird. Funct Ecol 22:649-654

Chambon R, Dugravot S, Paillisson J, Lemesle J, Ysnel F, Gelinaud G (2018) Partial migration in inexperienced Pied Avocets Recurvirostra avosetta: distribution pattern and correlates. J Avian Biol 49:e01549

Chan K (1995) Comparative study of winter body composition of resident and migrant Grey-breasted Silvereyes. Auk 112:421-428

Chan K (2001) Partial migration in Australian landbirds: a review. Emu 101:281-292

Chapman BB, Bronmark C, Nilsson JÅ, Hansson L (2011) The ecology and evolution of partial migration. Oikos 120:1764-1775

Clauss M, Dittmann MT, Mueller DWH, Meloro C, Codron D (2013) Bergmann's rule in mammals: a cross-species interspecific pattern. Oikos 122:1465-1472

Cobben MMP, van Noordwijk AJ (2016) Stable partial migration under a genetic threshold model of migratory behaviour. Ecography 39: $1210-1215$

Cobben MMP, van Noordwijk AJ (2017) Consequences of the genetic threshold model for observing partial migration under climate change scenarios. Ecol Evol 7:8379-8387

Cooper S (2002) Seasonal metabolic acclimatization in Mountain Chickadees and Juniper Titmice. Physiol Biochem Zool 75:386-395

Cooper-Mullin C, McWilliams SR (2016) The role of the antioxidant system during intense endurance exercise: lessons from migrating birds. J Exp Biol 219:3684-3695

Coppack T, Pulido F (2009) Proximate control and adaptive potential of protandrous migration in birds. Integr Comp Biol 49:493-506

Costantini D (2014) Oxidative stress and hormesis in evolutionary ecology and physiology. Springer, Berlin

Costantini D, Moller AP (2009) Does immune response cause oxidative stress in birds? A meta-analysis. Comp Biochem Phys A 153:339-344

Costantini D, Cardinale M, Carere C (2007) Oxidative damage and anti-oxidant capacity in two migratory bird species at a stop-over site. Comp Biochem Phys C 144:363-371

Crespi EJ, Williams TD, Jessop TS, Delehanty B (2013) Life history and the ecology of stress: how do glucocorticoid hormones influence life history variation in animals? Funct Ecol 27:93-106

Dawson A, King VM, Bentley GE, Ball GF (2001) Photoperiodic control of seasonality in birds. J Biol Rhythms 16:365-380

Dingle H (2008) Bird migration in the southern hemisphere: a review comparing continents. Emu 108:341-359

Eikenaar C, Hegemann A (2016) Migratory Common Blackbirds have lower innate immune function during autumn migration than resident conspecifics. Biol Lett 12:20160078

Eikenaar C, Klinner T, Stoewe M (2014) Corticosterone predicts nocturnal restlessness in a long-distance migrant. Horm Behav 66:324-329

Eikenaar C, Mueller F, Klinner T, Bairlein F (2015) Baseline corticosterone levels are higher in migrating than sedentary Common Blackbirds in autumn, but not in spring. Gen Comp Endocrinol 224:121-125

Eikenaar C, Kallstig E, Andersson MN, Herrera-Duenas A, Isaksson C (2017) Oxidative challenges of avian migration: a comparative field study on a partial migrant. Physiol Biochem Zool 90:223-229 
Eikenaar C, Ballstaedt E, Hessler S, Klinner T, Mueller F, Schmaljohann $\mathrm{H}$ (2018a) Cues, corticosterone and departure decisions in a partial migrant. Gen Comp Endocrinol 261:59-66

Eikenaar C, Isaksson C, Hegemann A (2018b) A hidden cost of migration? Innate immune function versus antioxidant defense. Ecol Evol 8:2721-2728

Ekman J (1979) Non-territorial Willow Tits Parus montanus in late summer and early autumn. Ornis Scand 10:262-267

Fudickar AM, Schmidt A, Hau M, Quetting M, Partecke J (2013) Female-biased obligate strategies in a partially migratory population. J Anim Ecol 82:863-871

Fudickar AM, Greives TJ, Atwell JW, Stricker CA, Ketterson ED (2016) Reproductive allochrony in seasonally sympatric populations maintained by differential response to photoperiod: implications for population divergence and response to climate change. Am Nat 187:436-446

Gauthreaux SA (1982) The ecology and evolution of avian migration systems. Anonymous, 6th edn. Academic Press, New York, pp 93-167

Gillis EA, Green DJ, Middleton HA, Morrissey CA (2008) Life history correlates of alternative migratory strategies in American Dippers. Ecology 89:1687-1695

Gilroy JJ, Gill JA, Butchart SHM, Jones VR, Franco AMA (2016) Migratory diversity predicts population declines in birds. Ecol Lett 19:308-317

Grist H, Daunt F, Wanless S, Nelson EJ, Harris MP, Newell M, Burthe S, Reid JM (2014) Site fidelity and individual variation in winter location in partially migratory European Shags. PLoS One 9:e98562

Grist H, Daunt F, Wanless S, Burthe SJ, Newell MA, Harris MP, Reid JM (2017) Reproductive performance of resident and migrant males, females and pairs in a partially migratory bird. J Anim Ecol 86:1010-1021

Griswold CK, Taylor CM, Norris DR (2011) The equilibrium population size of a partially migratory population and its response to environmental change. Oikos 120:1847-1859

Harris MP, Daunt F, Bogdanova MI, Lahoz-Monfort JJ, Newell MA, Phillips RA, Wanless S (2013) Inter-year differences in survival of Atlantic Puffins Fratercula arctica are not associated with winter distribution. Mar Biol 160:2877-2889

Hasselquist D (2007) Comparative immunoecology in birds: hypotheses and tests. J Ornithol 148:S571-S582

Hasselquist D, Nilsson JÅ (2012) Physiological mechanisms mediating costs of immune responses: what can we learn from studies of birds? Anim Behav 83:1303-1312

Hegemann A, van der Jeugd HP, de Graaf M, Oostebrink LL, Tieleman BI (2010) Are Dutch Skylarks partial migrants? Ring recovery data and radio-telemetry suggest local coexistence of contrasting migration strategies. Ardea 98:135-143

Hegemann A, Matson KD, Both C, Tieleman BI (2012a) Immune function in a free-living bird varies over the annual cycle, but seasonal patterns differ between years. Oecologia 170:605-618

Hegemann A, Matson KD, Versteegh MA, Tieleman BI (2012b) Wild skylarks seasonally modulate energy budgets but maintain energetically costly inflammatory immune responses throughout the annual cycle. PLoS ONE 7:e36358

Hegemann A, Matson KD, Versteegh MA, Villegas A, Tieleman BI (2013a) Immune response to an endotoxin challenge involves multiple immune parameters and is consistent among the annualcycle stages of a free-living temperate zone bird. J Exp Biol 216:2573-2580

Hegemann A, Matson KD, Flinks H, Tieleman BI (2013b) Offspring pay sooner, parents pay later: experimental manipulation of body mass reveals trade-offs between immune function, reproduction and survival. Front Zool 10:77
Hegemann A, Marra PP, Tieleman BI (2015) Causes and consequences of partial migration in a passerine bird. Am Nat 186:531-546

Hegemann A, Alcalde Abril P, Sjöberg S, Muheim R, Alerstam T, Nilsson J-Å, Hasselquist D (2018) A mimicked bacterial infection prolongs stopover duration in songbirds-but is more pronounced in short- than long-distance migrants. J Anim Ecol 87:1698-1708

Heldbjerg H, Karlsson L (1997) Autumn migration of Blue Tit Parus caeruleus at Falsterbo, Sweden 1980-94: population changes, migration patterns and recovery analysis. Ornis Svecica $7: 149-167$

Herremans M (1994) Partial migration in the Masked Weaver Ploceus Velatus in Southeastern Botswana. Ostrich 65:79-85

Holberton R (1999) Changes in patterns of corticosterone secretion concurrent with migratory fattening in a Neotropical migratory bird. Gen Comp Endocrinol 116:49-58

Horrocks NPC, Hegemann A, Matson KD, Hine K, Jaquier S, Shobrak M, Williams SB, Tinbergen JM, Tieleman BI (2012) Immune indexes of larks from desert and temperate regions show weak associations with life history but stronger links to environmental variation in microbial abundance. Physiol Biochem Zool 85:504-515

Horrocks NPC, Hegemann A, Ostrowski S, Ndithia H, Shobrak M, Williams JB, Matson KD, Tieleman BI (2015) Environmental proxies of antigen exposure explain variation in immune investment better than indices of pace of life. Oecologia 177:281-290

Ilmonen P, Taarna T, Hasselquist D (2000) Experimentally activated immune defence in female Pied Flycatchers results in reduced breeding success. Proc R Soc B 267:665-670

Ilmonen P, Kotrschal A, Penn DJ (2008) Telomere attrition due to infection. PLoS One 3:e2143

Jahn AE, Levey DJ, Hostetler JA, Mamani AM (2010) Determinants of partial bird migration in the Amazon Basin. J Anim Ecol 79:983-992

Jahn AE, Bravo SP, Cueto VR, Levey DJ, Morales MV (2012) Patterns of partial avian migration in northern and southern temperate latitudes of the New World. Emu 112:17-22

Jenni-Eiermann S, Jenni L, Smith S, Costantini D (2014) Oxidative stress in endurance flight: an unconsidered factor in bird migration. PLoS One 9:e97650

Kaitala A, Kaitala V, Lundberg P (1993) A theory of partial migration. Am Nat 142:59-81

Kersten M, Bruinzeel L, Wiersma P, Piersma T (1998) Reduced basal metabolic rate of migratory waders wintering in coastal Africa. Ardea 86:71-80

Ketterson ED (1979) Aggressive-behavior in wintering Dark-eyed Juncos-determinants of dominance and their possible relation to geographic-variation in sex-ratio. Wilson Bull 91:371-383

Ketterson ED, Nolan V (1976) Geographic variation and its climatic correlates in sex-ratio of eastern-wintering Dark-eyed Juncos (Junco hyemalis hyemalis). Ecology 57:679-693

Khaliq I, Boehning-Gaese K, Prinzinger R, Pfenninger M, Hof C (2017) The influence of thermal tolerances on geographical ranges of endotherms. Global Ecol Biogeogr 26:650-668

Kitano J, Lema SC, Luckenbach JA, Mori S, Kawagishi Y, Kusakabe M, Swanson P, Peichel CL (2010) Adaptive divergence in the thyroid hormone signaling pathway in the stickleback radiation. Curr Biol 20:2124-2130

Kitano J, Ishikawa A, Kume M, Mori S (2012) Physiological and genetic basis for variation in migratory behavior in the Threespined Stickleback, Gasterosteus aculeatus. Ichthyol Res 59:293-303

Klaassen M, Hoye BJ, Nolet BA, Buttemer WA (2012) Ecophysiology of avian migration in the face of current global hazards. Philos Trans R Soc B 367:1719-1732 
Klasing KC (2004) The costs of immunity. Acta Zool Sinica 50:961-969

Kokko H (2011) Directions in modelling partial migration: how adaptation can cause a population decline and why the rules of territory acquisition matter. Oikos 120:1826-1837

Kralj J, Jurinovic L, Barisic S, Cikovic D, Tutis V (2018) Apparent survival rates of a long-lived partial migrant: the Yellowlegged Gull Larus michahellis. Bird Study 65:189-196

Lack D (1943) The problem of partial migration. Br Birds 37:122-130

Lee KA, Martin LB, Wikelski MC (2005) Responding to inflammatory challenges is less costly for a successful avian invader, the House Sparrow (Passer domesticus), than its less-invasive congener. Oecologia 145:244-251

Lees AC (2016) Evidence for longitudinal migration by a "sedentary" Brazilian flycatcher, the Ash-throated Casiornis. J Field Ornithol 87:251-259

Lindström $\AA$ (1997) Basal metabolic rates of migrating waders in the Eurasian Arctic. J Avian Biol 28:87-92

Lindström A, Klaassen M, Kvist A (1999) Variation in energy intake and basal metabolic rate of a bird migrating in a wind tunnel. Funct Ecol 13:352-359

Lipshutz S, Remisiewicz M, Underhill LG, Avni J (2011) Seasonal fluctuations in population size and habitat segregation of Kittlitz's Plover Charadrius pecuarius at Barberspan Bird Sanctuary, North West Province, South Africa. Ostrich 82:207-215

Lundberg P (1987) Partial bird migration and evolutionarily stable strategies. J Theor Biol 125:351-360

Lundberg P (1988) The evolution of partial migration in birds. Trends Ecol Evol 3:172-175

Lundberg P (2013) On the evolutionary stability of partial migration. J Theor Biol 321:36-39

Macdonald CA, McKinnon EA, Gilchrist HG, Love OP (2016) Cold tolerance, and not earlier arrival on breeding grounds, explains why males winter further north in an Arctic-breeding songbird. J Avian Biol 47:7-15

Martell M, McMillian M, Solensky M, Mealey B (2004) Partial migration and wintering use of Florida by Ospreys. J Raptor Res 38:55-61

McKilligan N, Reimer D, Seton D, Davidson D, Willows J (1993) Survival and seasonal movements of the Cattle Egret in Eastern Australia. Emu 93:79-87

McEwen BS, Wingfield JC (2003) The concept of allostasis in biology and biomedicine. Horm Behav 43:2-15

Middleton H, Morrissey C, Green D (2006) Breeding territory fidelity in a partial migrant, the American Dipper Cinclus mexicanus. J Avian Biol 37:169-178

Møller AP, Erritzoe J (1998) Host immune defence and migration in birds. Evol Ecol 12:945-953

Monaghan P (2010) Telomeres and life histories. the long and the short of it. Year Evol Biol 1206:130-142

Monaghan P, Metcalfe NB, Torres R (2009) Oxidative stress as a mediator of life history trade-offs: mechanisms, measurements and interpretation. Ecol Lett 12:75-92

Nathan R, Getz WM, Revilla E, Holyoak M, Kadmon R, Saltz D, Smouse PE (2008) A movement ecology paradigm for unifying organismal movement research. PNAS 105:19052-19059

Newton I (2008) The migration ecology of birds. Elsevier/Academic Press, Amsterdam

Nilsson JA (2002) Metabolic consequences of hard work. Proc R Soc B 269:1735-1739

Nilsson JA, Nord A (2018) Testing the heat dissipation limit theory in a breeding passerine. Proc R Soc B 285:20180652

Nilsson ALK, Sandell MI (2009) Stress hormone dynamics: an adaptation to migration? Biol Lett 5:480-483
Nilsson JÅ, Svensson E (1996) The cost of reproduction: a new link between current reproductive effort and future reproductive success. Proc R Soc B 263:711-714

Nilsson ALK, Lindström Å, Jonzen N, Nilsson SG, Karlsson L (2006) The effect of climate change on partial migration-the Blue Tit paradox. Global Change Biol 12:2014-2022

Nilsson ALK, Alerstam T, Nilsson JÅ (2008) Diffuse, short and slow migration among Blue Tits. J Ornithol 149:365-373

Nilsson ALK, Nilsson JA, Alerstam T (2011) Basal metabolic rate and energetic cost of thermoregulation among migratory and resident Blue Tits. Oikos 120:1784-1789

Nilsson JÅ, Molokwu MN, Olsson O (2016) Body temperature regulation in hot environments. PLoS One 11:e0161481

Norbu N, Ugyen Wikelski MC, Wilcove DS (2017) Partial altitudinal migration of the Near Threatened Satyr Tragopan Tragopan satyra in the Bhutan Himalayas: implications for conservation in mountainous environments. Oryx 51:166-173

Novoa F, Bozinovic F, Rosenmann M (1994) Seasonal-changes of thermal conductance in Zonotrichia capensis (Emberizidae), from Central Chile - the role of plumage. Comp Biochem Phys A 107:297-300

Owen JC, Garvin MC, Moore FR (2014) Elevated testosterone advances onset of migratory restlessness in a Nearctic-Neotropical landbird. Behav Ecol Sociobiol 68:561-569

Owen-Ashley NT, Wingfield JC (2007) Acute phase responses in passerine birds: characterization and seasonal variation. J Ornithol 148:583-591

Owen-Ashley NT, Turner M, Hahn TP, Wingfield JC (2006) Hormonal, behavioral, and thermoregulatory responses to bacterial lipopolysaccharide in captive and free-living White-crowned Sparrows (Zonotrichia leucophrys gambelii). Horm Behav 49:15-29

Palacin C, Alonso JC, Alonso JA, Magana M, Martin CA (2011) Cultural transmission and flexibility of partial migration patterns in a long-lived bird, the Great Bustard Otis tarda. J Avian Biol 42:301-308

Palacin C, Alonso JC, Martin CA, Alonso JA (2012) The importance of traditional farmland areas for steppe birds: a case study of migrant female Great Bustards Otis tarda in Spain. Ibis 154:85-95

Peiman KS, Birnie-Gauvin K, Larsen MH, Colborne SF, Gilmour KM, Aarestrup K, Willmore WG, Cooke SJ (2017a) Morphological, physiological and dietary covariation in migratory and resident adult Brown Trout (Salmo trutta). Zoology 123:79-90

Peiman KS, Birnie-Gauvin K, Midwood JD, Larsen MH, Wilson ADM, Aarestrup K, Cooke SJ (2017b) If and when: intrinsic differences and environmental stressors influence migration in Brown Trout (Salmo trutta). Oecologia 184:375-384

Perez C, Granadeiro JP, Dias MP, Alonso H, Catry P (2014) When males are more inclined to stay at home: insights into the partial migration of a pelagic seabird provided by geolocators and isotopes. Behav Ecol 25:313-319

Pratt AC, Smith KT, Beck JL (2017) Environmental cues used by Greater Sage-grouse to initiate altitudinal migration. Auk 134:628-643

Pulido F (2011) Evolutionary genetics of partial migration - the threshold model of migration revis(it)ed. Oikos 120:1776-1783

Pulido F, Berthold P (2010) Current selection for lower migratory activity will drive the evolution of residency in a migratory bird population. Proc Natl Acad Sci 107:7341-7346

Ramenofsky M (2011) Hormones in migration and reproductive cycles of birds. In: Norris D, Lopez KH (eds) Hormones and reproduction of vertebrates: birds. Academic Press, Cambridge, pp 205-237

Reid JM, Travis JMJ, Daunt F, Burthe SJ, Wanless S, Dytham C (2018) Population and evolutionary dynamics in spatially structured seasonally varying environments. Biol Rev 93:1578-1603 
Roitt IM, Brostoff J, Male DK (1998) Immunology. Mosby, London, Philadelphia

Romero LM, Cyr NE, Romero RC (2006) Corticosterone responses change seasonally in free-living House Sparrows (Passer domesticus). Gen Comp Endocrinol 149:58-65

Salomons HM, Mulder GA, van de Zande L, Haussmann MF, Linskens MHK, Verhulst S (2009) Telomere shortening and survival in free-living corvids. Proc R Soc B 276:3157-3165

Scanes CG (2015) Pituitary gland. In: Scanes CG (ed) Sturkie's avian physiology, sixth edn. Academic Press, pp 497-533

Schwabl H (1983) Expression and significance of the winter strategies in a partially migratory population of European Blackbirds (Turdus merula). J Ornithol 124:101-116

Schwabl H, Silverin B (1990) Control of partial migration and autumnal behaviour. In: Gwinner E (ed) Bird migration: physiology and ecophysiology. Springer, Berlin, pp 144-155

Schwabl H, Wingfield JC, Farner DS (1984) Endocrine correlates of autumnal behavior in sedentary and migratory individuals of a partially migratory population of the European Blackbird (Turdus merula). Auk 101:499-507

Shaw AK, Binning SA (2016) Migratory recovery from infection as a selective pressure for the evolution of migration. Am Nat 187:491-501

Silverin B (1984) Annual gonadotropin and testosterone cycles in freeliving male birds. J Exp Zool 232:581-587

Silverin B, Viebke P, Westin J (1989) Hormonal correlates of migration and territorial behavior in juvenile Willow Tits during autumn. Gen Comp Endocrinol 75:148-156

Sköld-Chiriac S, Nord A, Tobler M, Nilsson JÅ, Hasselquist D (2015) Body temperature changes during simulated bacterial infection in a songbird: fever at night and hypothermia during the day. $\mathbf{J}$ Exp Biol 218:2961-2969

Smit B, Whitfield MC, Talbot WA, Gerson AR, McKechnie AE, Wolf BO (2018) Avian thermoregulation in the heat: phylogenetic variation among avian orders in evaporative cooling capacity and heat tolerance. J Exp Biol 221:jeb174870

Smith HG, Nilsson JA (1987) Intraspecific variation in migratory pattern of a partial migrant, the Blue Tit (Parus caeruleus) - an evaluation of different hypotheses. Auk 104:109-115

Stearns SC (1976) Life history tactics: a review of the ideas. Q Rev Biol 51:4-47

Swanson D (1993) Cold tolerance and thermogenic capacity in Darkeyed Juncos in winter-geographic-variation and comparison with American Tree Sparrows. J Therm Biol 18:275-281
Swanson DL (2010) Seasonal metabolic variation in birds: functional and mechanistic correlates. Current Ornithol 17:75-129

Terrill SB, Able KP (1988) Bird migration terminology. Auk 105:205-206

Tonra CM, Marra PP, Holberton RL (2011) Early elevation of testosterone advances migratory preparation in a songbird. J Exp Biol 214:2761-2767

van Dijk JGB, Matson KD (2016) Ecological immunology through the lens of exercise immunology: new perspective on the links between physical activity and immune function and disease susceptibility in wild animals. Integr Comp Biol 56:290-303

van Dijk JGB, Hoye BJ, Verhagen JH, Nolet BA, Fouchier RAM, Klaassen M (2014) Juveniles and migrants as drivers for seasonal epizootics of avian influenza virus. J Anim Ecol 83:266-275

van Wijk RE, Schaub M, Hahn S, Juarez-Garcia-Pelayo N, Schafer B, Viktora L, Martin-Vivaldi M, Zischewski M, Bauer S (2018) Diverse migration strategies in Hoopoes (Upupa epops) lead to weak spatial but strong temporal connectivity. Sci Nat 105:42

von Schantz T, Bensch S, Grahn M, Hasselquist D, Wittzell H (1999) Good genes, oxidative stress and condition-dependent sexual signals. Proc R Soc B 266:1-12

Vukovich M, Kilgo JC (2013) Fall movements of Red-headed Woodpeckers in South Carolina. J Field Ornithol 84:193-200

Weimerskirch H, Delord K, Guitteaud A, Phillips RA, Pinet P (2015) Extreme variation in migration strategies between and within Wandering Albatross populations during their sabbatical year, and their fitness consequences. Sci Rep 5:8853

Wikelski M, Tarlow EM, Raim A, Diehl RH, Larkin RP, Visser GH (2003) Costs of migration in free-flying songbirds. Nature 423:704

Wilbourn RV, Moatt JP, Froy H, Walling CA, Nussey DH, Boonekamp JJ (2018) The relationship between telomere length and mortality risk in non-model vertebrate systems: a meta-analysis. Philos Trans R Soc B 373:20160447

Wilcoxen TE, Boughton RK, Schoech SJ (2010) Selection on innate immunity and body condition in Florida Scrub-jays throughout an epidemic. Biol Lett 6:552-554

Publisher's Note Springer Nature remains neutral with regard to jurisdictional claims in published maps and institutional affiliations.

\section{Affiliations}

\section{Arne Hegemann $^{1}$ · Adam M. Fudickar ${ }^{2,3}$. Jan-Åke Nilsson ${ }^{1}$}

Jan-Åke Nilsson

jan-ake.nilsson@biol.lu.se

1 Department of Biology, Lund University, Ecology Building, 22362 Lund, Sweden
2 Environmental Resilience Institute, Indiana University, Bloomington, USA

3 Department of Biology, Indiana University, Bloomington, USA 